\title{
Effect of Dieckol, a Component of Ecklonia cava, on the Promotion of Hair Growth
}

\section{Jung-Il Kang ${ }^{1}$, Sang-Cheol Kim ${ }^{1}$, Min-Kyoung Kim ${ }^{1}$, Hye-Jin Boo ${ }^{1}$, You-Jin Jeon ${ }^{2,3}$, Young-Sang Koh ${ }^{1}$, Eun-Sook Yoo ${ }^{1}$, Sung-Myung Kang ${ }^{3}$ and Hee-Kyoung Kang ${ }^{1}{ }^{*}$}

1 Department of Medicine, School of Medicine, Jeju National University, 102 Jejudaehakno, Jeju 690-756, Korea; E-Mails: asdkji@ hanmail.net (J.-I.K.); 25008@hanmail.net (S.-C.K.); loveis6776@ hanmail.net (M.-K.K.); wonsein2000@ nate.com (H.-J.B.); yskoh7@jejunu.ac.kr (Y.-S.K.); eunsyoo@jejunu.ac.kr (E.-S.Y.)

2 Aqua Green Technology Co. Ltd., 209 Jeju Bio-Industry Center, 102 Jejudaehakno, Jeju 690-121, Korea; E-Mail: youjinj@jejunu.ac.kr

3 Department of Marine Life Science, Jeju National University, 102 Jejudaehakno, Jeju 690-756, Korea; E-Mail: tjdaud81@ hanmail.net

* Author to whom correspondence should be addressed; E-Mail: pharmkhk@jejunu.ac.kr; Tel.: +82-64-754-3846; Fax: +82-64-702-2687.

Received: 2 March 2012; in revised form: 13 April 2012 / Accepted: 14 May 2012 / Published: 23 May 2012

\begin{abstract}
This study was conducted to evaluate the effect of Ecklonia cava, a marine alga native to Jeju Island in Korea, on the promotion of hair growth. When vibrissa follicles were cultured in the presence of E. cava enzymatic extract (which contains more than $35 \%$ of dieckol) for 21 days, E. cava enzymatic extract increased hair-fiber length. In addition, after topical application of the $0.5 \%$ E. cava enzymatic extract onto the back of C57BL/6 mice, anagen progression of the hair-shaft was induced. The treatment with E. cava enzymatic extract resulted in the proliferation of immortalized vibrissa dermal papilla cells (DPC). Especially, dieckol, among the isolated compounds from the E. cava enzymatic extract, showed activity that increased the proliferation of DPC. When NIH3T3 fibroblasts were treated with the E. cava enzymatic extract and the isolated compounds from the E. cava enzymatic extract, the E. cava enzymatic extract increased the proliferation of NIH3T3 fibroblasts, but the isolated compounds such as eckol, dieckol, phloroglucinol and triphlorethol-A did not affect the proliferation of NIH3T3 fibroblasts. On the other hand, the E. cava enzymatic extract and dieckol significantly inhibited $5 \alpha$-reductase activity.
\end{abstract}


These results suggest that dieckol from E. cava can stimulate hair growth by the proliferation of DPC and/or the inhibition of $5 \alpha$-reductase activity.

Keywords: Ecklonia cava; dieckol; hair growth; dermal papilla cells; $5 \alpha$-reductase activity; vibrissa follicle; C57BL/6 mice

\section{Introduction}

Androgenetic alopecia (AGA), the most common type of alopecia, is a problem in men over the age of 40. Hair loss is a growing trend in the world, however, the prevention of this condition is not simple [1]. Numerous possibilities have been discussed to treat hair loss [2]. Nevertheless, only two FDA-approved drugs have been available for AGA patients, i.e., finasteride and minoxidil $[3,4]$. Finasteride is a type II $5 \alpha$-reductase inhibitor. It can be used in prostatic hypertrophy [5] as well as in hair loss [6]. Minoxidil was used as a drug to treat high blood pressure [7]. However, it was also found to promote hair growth [8,9], although the mechanism of minoxidil-induced hair growth is not fully understood. In a previous study, minoxidil was shown to have proliferative and anti-apoptotic effects on dermal papilla cells [10]. Moreover, it was also found to stimulate hair growth by the opening of ATP-sensitive $\mathrm{K}^{+}$-channel [11,12], the up-regulation of vascular endothelial growth factor (VEGF) [13] and the activation of the $\beta$-catenin pathway [14] in dermal papilla cells (DPC). The DPC consist of a cluster of specialized fibroblasts that play important roles in the regulation of the hair cycle through the secretion of diffusible proteins, such as insulin-like growth factor-1 (IGF-1) [15], hepatocyte growth factor (HGF) [16], VEGF [13] and transforming growth factor- $\beta$ (TGF- $\beta$ ) [17,18].

Ecklonia cava, a brown alga, grows in the regions of Jeju Island in Korea. In previous reports, E. cava has been found to have effects such as anti-bacterial [19] and anti-inflammatory activity [20]. E. cava has been reported to contain various phlorotannins-such as eckol, 8,8'-bieckol, 8,4'-dieckol, phlorofucofuroeckol A, triphlorethol-A, phloroglucinol, dioxinodehydroeckol, fucodiphlorethol G [21-24]. Eckol was reported to have radioprotective activities [25], dieckol to have anti-inflammatory effects [26], and triphlorethol-A to have antioxidant activity [22,23]. Recently, it has been found that phloroglucinol induced apoptosis [24]. However, the effect and the underlying mechanisms of E. cava on hair growth have not been described. In this study, we examined the promotion effects and the mechanisms of E. cava extract and its components (eckol, dieckol, triphlorethol-A and phloroglucinol) on hair growth.

\section{Results}

\subsection{The Effect of Ecklonia cava Enzymatic Extract on the Hair-Fiber Elongation of Rat Vibrissa Follicle}

To determine whether $E$. cava enzymatic extract could induce hair growth, we examined the effect of E. cava enzymatic extract with the use of an organ culture of the rat vibrissa follicle. When the rat vibrissa follicles were treated with various concentrations of $E$. cava enzymatic extract for three weeks, in particular, the hair-fiber length with $1 \mu \mathrm{g} / \mathrm{mL}$ of $E$. cava enzymatic extract treatment showed a 
significant increase when compared to the control group (Figure 1). The result indicates that E. cava enzymatic extract contains components promoting hair growth.

Figure 1. Hair growth effect of Ecklonia cava enzymatic extract on rat vibrissa follicles. $(\mathbf{A}, \mathbf{B})$ Individual vibrissa follicles from Wistar rats were micro dissected and then cultured in William's $\mathrm{E}$ medium at $37{ }^{\circ} \mathrm{C}$ under $5 \% \mathrm{CO}_{2}$. Vibrissa follicles were treated with various concentrations of $E$. cava enzymatic extract and minoxidil sulfate, as indicated. All experiments were performed in triplicate. The difference in the length of vibrissa follicles of the control group on day 21 was taken to be $100 \%$. Data are presented as the percentage of the length of the treated follicles based on the mean length of the control follicles \pm SE. $* p<0.05, * * p<0.01 v s$. control.

A

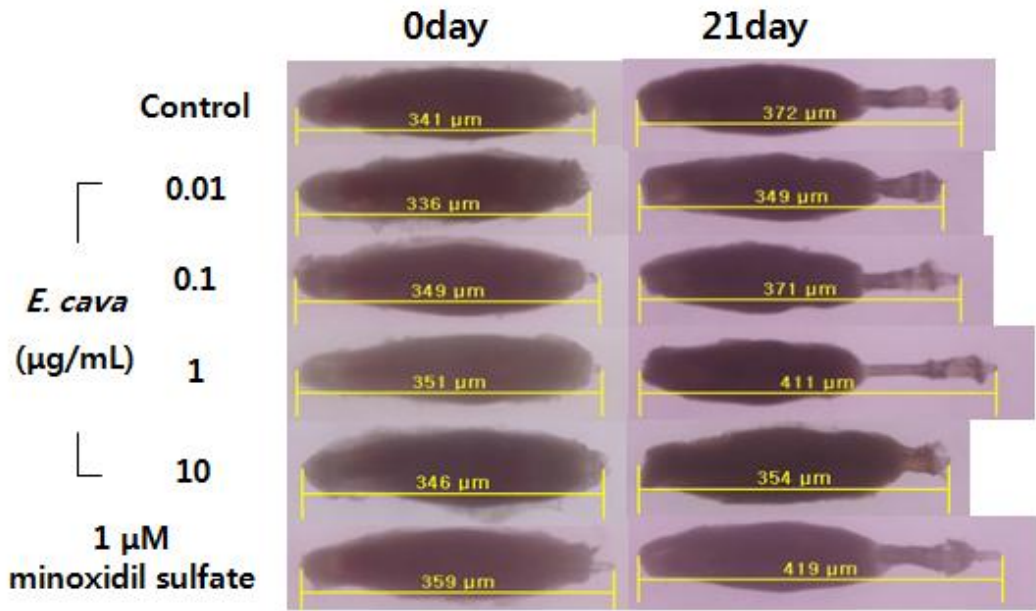

B

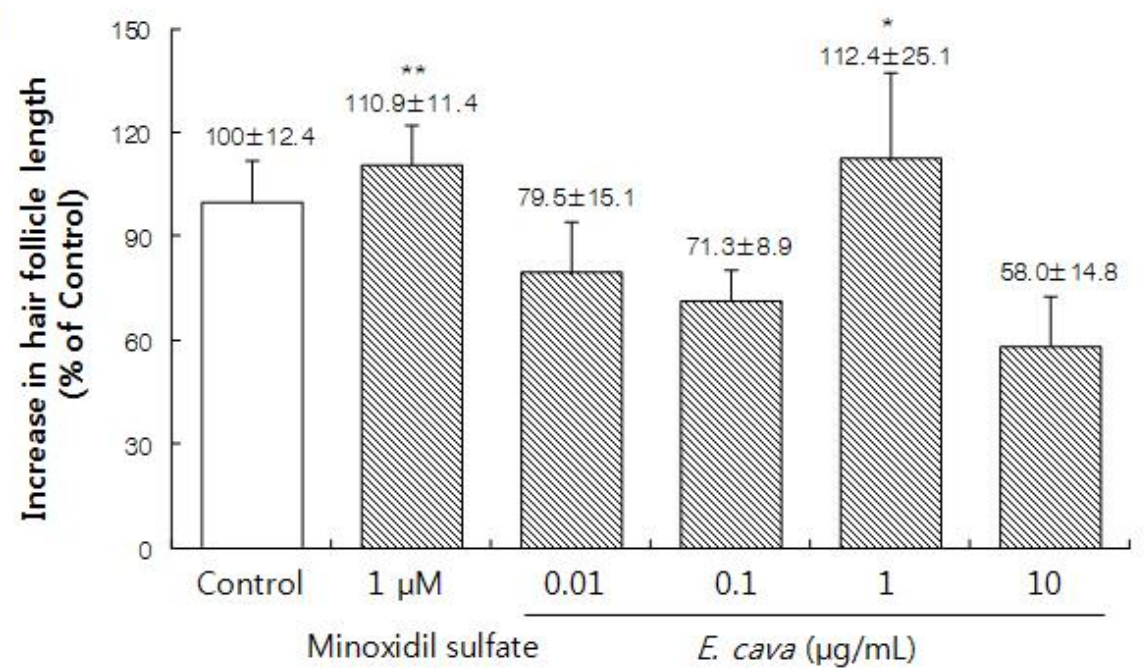

\subsection{The Effect of Ecklonia cava Enzymatic Extract on the Anagen Induction in C57BL/6 Mice}

To investigate whether anagen induction was promoted by $E$. cava enzymatic extract, we used C57BL/6 mice, since the dorsal hair is known to have a time-synchronized hair growth cycle [27]. Shaved skin of telogen C57BL/6 mice is pink, which then darkens along with anagen initiation. As shown in Figure 2, the area of black skin was significantly larger $(p<0.05)$ in the $0.5 \%$ E. cava enzymatic extract treated group than in the control group at 26 days after depilation. Induction of the 
anagen phase in the $0.5 \% \mathrm{E}$. cava enzymatic extract treated group was observed to be faster than in the control group. The 5\% Minoxidil (MINOXYL ${ }^{\mathrm{TM}}$ ) treated group, a positive control group, showed gray skin from 13 days after depilation.

Figure 2. The effect of Ecklonia cava enzymatic extract on the anagen induction in C57BL/6 mice. After shaving, the back skins were treated with $0.5 \%$ E. cava enzymatic extract, vehicle and 5\% minoxidil every day for 33 days. (A) The back skins were photographed at 1, 7, 13, 20, 26 and 33 days after depilation; (B) On day 26, the quantitative assessment of anagen induction analyzed via dotmatrix planimetry was performed. The transparency was put on a photo of a mouse to mark the areas that were in different stages $($ pink $=$ telogen, anagen $=$ black). Afterward a dotmatrix (sheet with a uniform defined dot pattern) was placed under the marked foil to calculate the percentages of the regions of interest by counting the dots. The percentage of anagen induction was calculated by the equation [(black skin/total skin) $\times 100$ ]. Data are presented as the mean $\pm \mathrm{SE}$ $(n=6) . * p<0.05, * * p<0.01, * * * p<0.001 v s$. vehicle treated control.

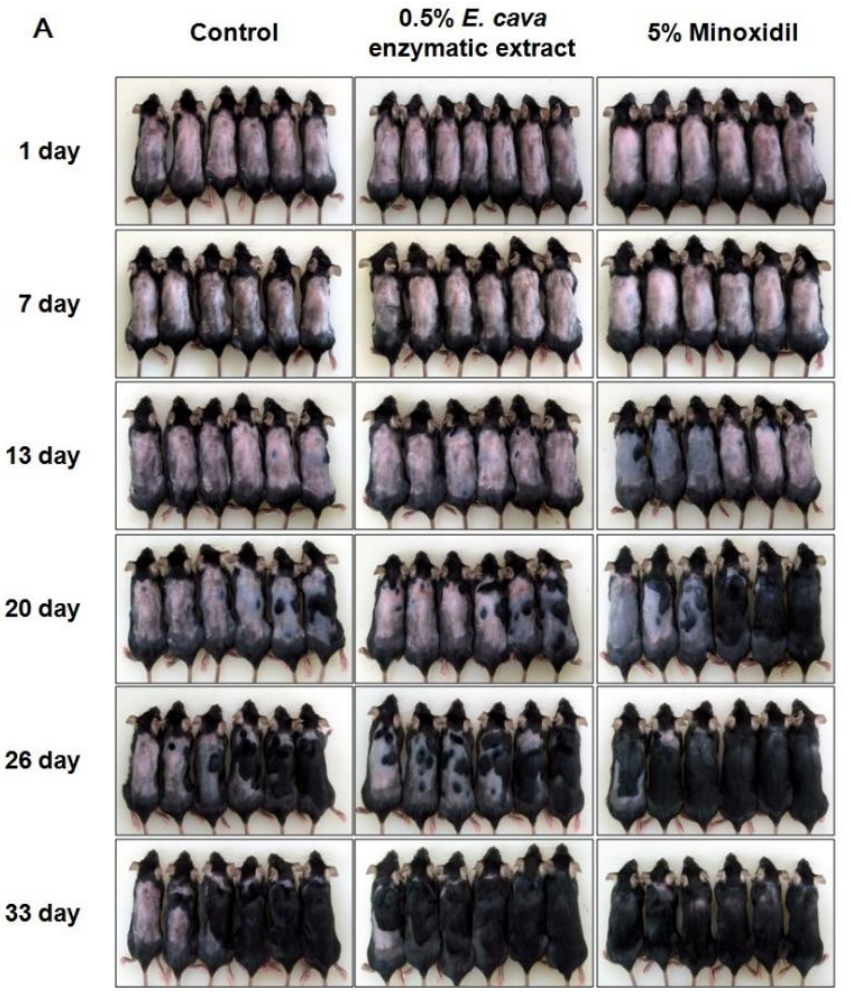

B

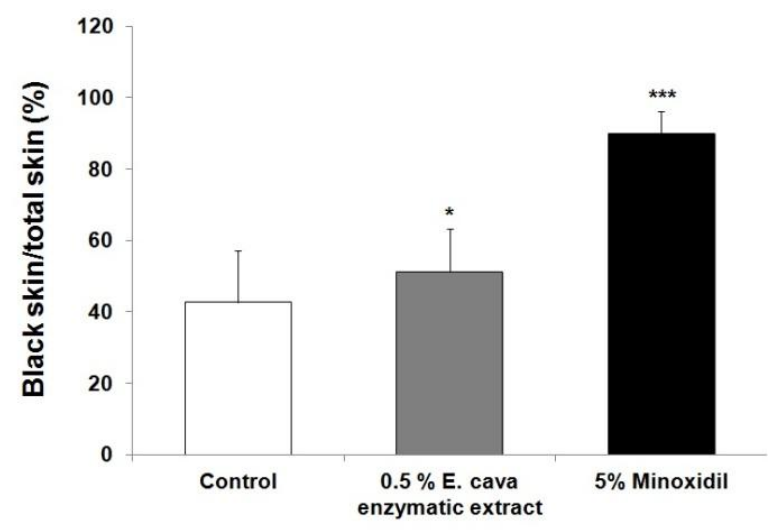

2.3. The Effects of Ecklonia cava Enzymatic Extract and Its Isolated Compounds on the Proliferation of Dermal Papilla Cells

We examined the effects of E. cava enzymatic extract and its isolated compounds on the proliferation of DPC. When DPC were treated with E. cava enzymatic extract in the concentrations of $0.001,0.01,0.1,1,10$ and $100 \mu \mathrm{g} / \mathrm{mL}, E$. cava enzymatic extract significantly promoted the proliferation of DPC compared with the vehicle-treated control at all the concentrations, except the $100 \mu \mathrm{g} / \mathrm{mL}$ (Figure 3). We evaluated whether the isolated compounds from $E$. cava enzymatic extract such as eckol, dieckol, phloroglucinol and triphlorethol-A, could promote the proliferation of DPC. 
DPC were treated with eckol, dieckol, phloroglucinol and triphlorethol-A, individually, at $0.005,0.01$, $0.05,0.1,0.5,1$ and $10 \mu \mathrm{g} / \mathrm{mL}$ for 4 days. The dieckol increased the proliferation of DPC by $100.5 \%$, $103.9 \%, 113.5 \%, 106.1 \%, 108.1 \%, 98.5 \%$ and $97.3 \%$, respectively (Table 1). The eckol also promoted the proliferation of DPC by $100.8 \%, 106.1 \%, 120.3 \%, 108.5 \%, 107.8 \%, 105.4 \%$ and $104.1 \%$, respectively (Table 1). However, phloroglucinol and triphlorethol-A did not affect the proliferation of DPC (Table 1).

Figure 3. The effect of Ecklonia cava enzymatic extract on the proliferation of dermal papilla cells. Rat vibrissa immortalized DPC $\left(1.0 \times 10^{4}\right.$ cells $\left./ \mathrm{mL}\right)$ were plated in 96 well plates. DPC were treated with various concentrations of $E$. cava enzymatic extract and minoxidil sulfate, as indicated. Cell proliferation was measured using a MTT assay for 4 days. All experiments were performed in triplicate. Data are presented as the mean \pm SD. $* p<0.05, * * p<0.01, * * * p<0.001 v s$. control.

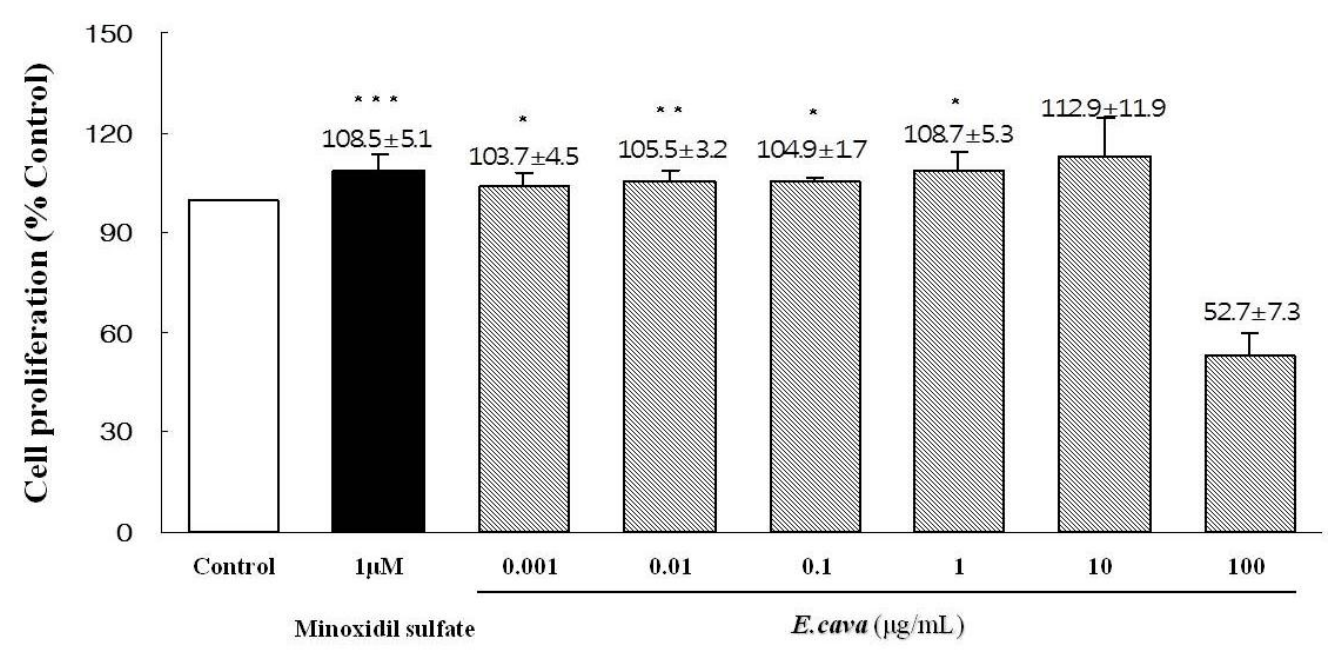

Table 1. The effects of isolated compounds from Ecklonia cava enzymatic extract on the proliferation of dermal papilla cells.

\begin{tabular}{ccccc}
\hline \multirow{2}{*}{ Concentration $(\boldsymbol{\mu g} / \mathbf{m L})$} & \multicolumn{4}{c}{ Compounds } \\
\cline { 2 - 5 } & Eckol & Dieckol & Phloroglucinol & Triphlorethol-A \\
\hline 0.005 & $100.8 \pm 1.6^{*}$ & $100.5 \pm 4.7 * *$ & $102.0 \pm 8.5$ & $101.7 \pm 7.9$ \\
0.01 & $106.1 \pm 4.5 *$ & $103.9 \pm 6.5$ & $100.4 \pm 6.8$ & $102.9 \pm 3.5$ \\
0.05 & $120.3 \pm 9.9$ & $113.5 \pm 6.2 *$ & $96.4 \pm 5.3$ & $100.4 \pm 8.2$ \\
0.1 & $108.5 \pm 7.7$ & $106.1 \pm 5.4$ & $99.6 \pm 4.7$ & $99.3 \pm 5.2$ \\
0.5 & $107.8 \pm 6.7$ & $108.1 \pm 6.2$ & $99.2 \pm 4.0$ & $99.4 \pm 7.7$ \\
1 & $105.4 \pm 6.2$ & $98.5 \pm 6.5$ & $98.3 \pm 2.3$ & $103.3 \pm 7.5$ \\
10 & $104.1 \pm 9.7$ & $97.8 \pm 3.9$ & $76.8 \pm 5.6$ & $100.6 \pm 4.5$ \\
\hline
\end{tabular}

The proliferation of the control group was regarded as $100 \%$ (not shown). All experiments were performed in triplicate. Data are presented as the mean \pm SD. $* p<0.05, * * p<0.01, * * * p<0.001 v s$. control. 


\subsection{The Effects of Ecklonia cava Enzymatic Extract and Its Isolated Compounds on the Proliferation} of NIH3T3 Fibroblasts

Minoxidil, a hair-growth promoting agent, has a mitotic effect on NIH3T3 fibroblasts via $\mathrm{K}_{\mathrm{ATP}}$ channel opening. Whether E. cava enzymatic extract, eckol, dieckol, phloroglucinol and triphlorethol-A could act as an opener of $\mathrm{K}_{\text {ATP }}$ channel, proliferation of NIH3T3 fibroblasts was examined. NIH3T3 fibroblasts were treated with E. cava enzymatic extract, eckol, dieckol, phloroglucinol and triphlorethol-A at $0.05,0.1,0.5,1$ and $10 \mu \mathrm{g} / \mathrm{mL}$. The E. cava enzymatic extract significantly increased the proliferation of NIH3T3 fibroblasts by $119.6 \%, 118.8 \%, 116.3 \%, 113.7 \%$ and $77.4 \%$, respectively (Figure 4A). To evaluate whether the E. cava-induced proliferation was mediated through $\mathrm{K}_{\mathrm{ATP}}$ channel opening, NIH3T3 fibroblasts were pretreated with tolbutamide, a non-selective blocker of $\mathrm{K}^{+}$channels. Tolbutamide inhibited the $E$. cava-induced proliferation of NIH3T3 fibroblasts (Figure 4B). Nevertheless, it is important to note that dieckol, a major component of the E. cava enzymatic extract, did not alter the proliferation of NIH3T3 fibroblasts (data not shown). Eckol, phloroglucinol and triphlorethol-A slightly increased the proliferation of NIH3T3 fibroblasts compared with the control group (data not shown).

Figure 4. The effect of Ecklonia cava enzymatic extract on the proliferation of NIH3T3 fibroblasts. (A,B) Mouse embryonic NIH3T3 fibroblasts $\left(1.0 \times 10^{4}\right.$ cells $\left./ \mathrm{mL}\right)$ were plated in 96 well plates. NIH3T3 fibroblasts were treated with various concentration of E. cava enzymatic extract, as indicated. Stimulation with minoxidil served as a positive control. (B) NIH3T3 fibroblasts were pretreated with tolbutamide for $30 \mathrm{~min}$ prior to incubation with E. cava enzymatic extract. Cell proliferation was measured using a MTT assay for four days. All experiments were performed in triplicate. Data are presented as the mean \pm SD. $* p<0.05, * * p<0.01, * * * p<0.001$ vs. control; ${ }^{\# \#} p<0.001$ vs. E. cava-treated group.

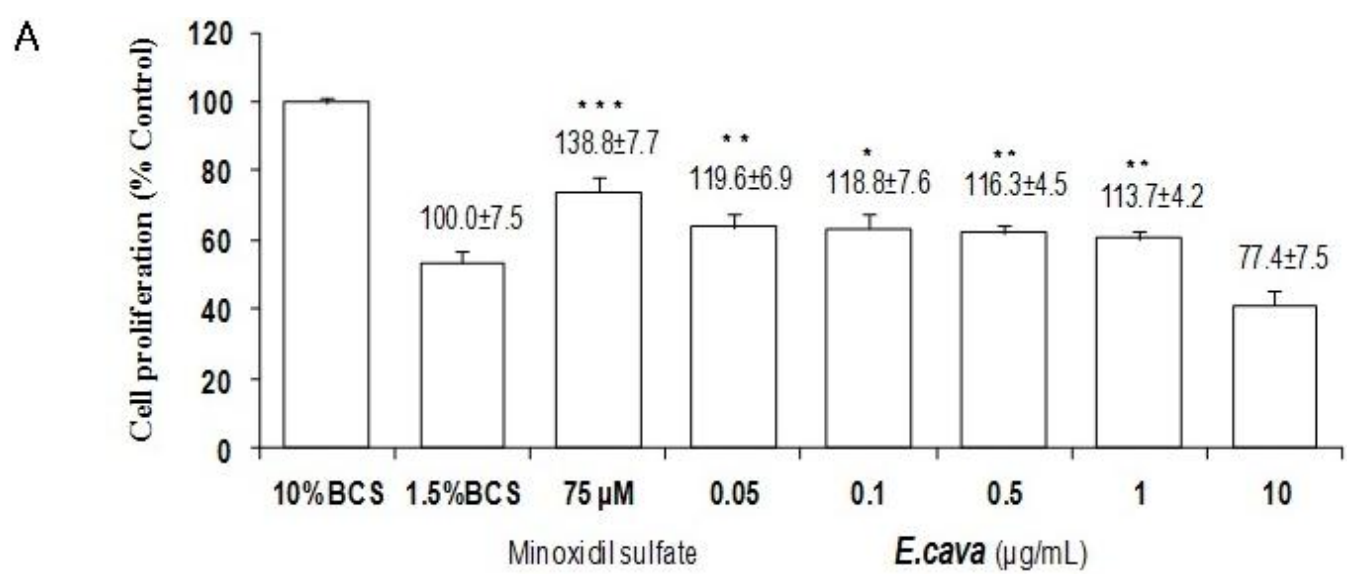


Figure 4. Cont.

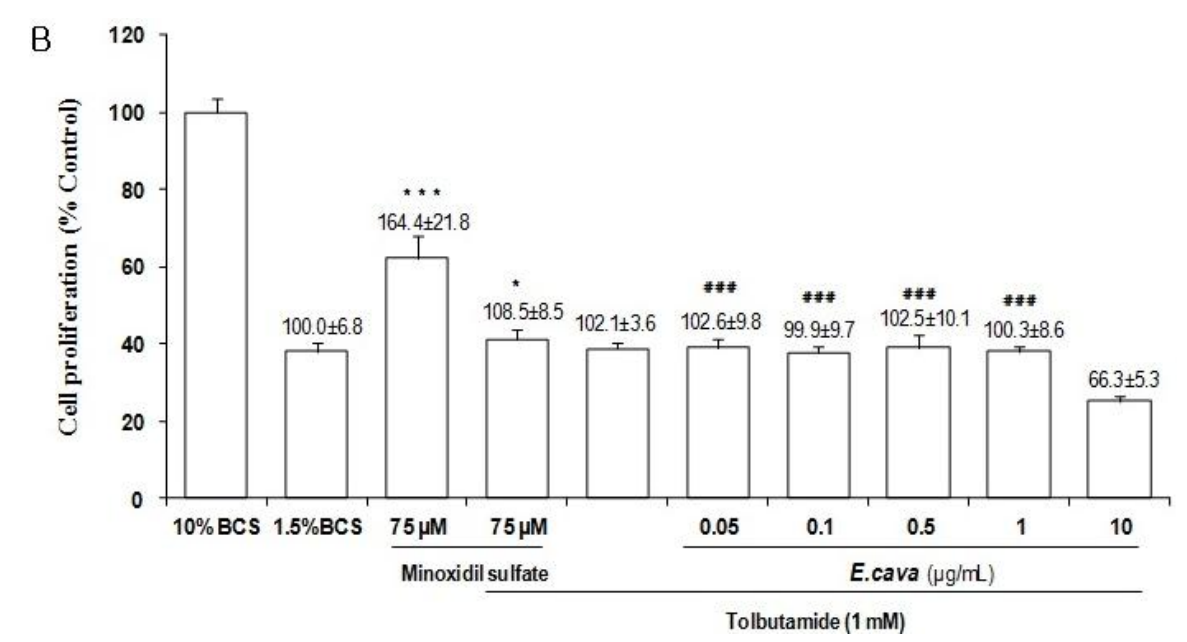

2.5. The Effects of Ecklonia cava Enzymatic Extract and Its Isolated Compounds on

\section{5a-Reductase Activities}

Figure 5. Inhibition effects of Ecklonia cava enzymatic extract and its isolated compounds on $5 \alpha$-reductase activities. (A-E) Assay of $5 \alpha$-reductase inhibition was performed using a crude extract of rat prostate. The reaction mixture contained $\left[1,2,6,7-{ }^{3} \mathrm{H}\right]$ testosterone, prostatic enzyme and E. cava enzymatic extract or its isolated compounds (eckol, dieckol, phloroglucinol and triphlorethol-A). The conversion rate of testosterone (T) to dihydrotestosterone (DHT) was calculated by the equation [DHT/(T + DHT)]. Inhibition activity (\%) was expressed as a percentage of reduced conversion rate compared to the control. The inhibition activity of control group was regarded as $0 \%$ (not shown). Finasteride was used as a positive control. Data are presented as the mean \pm SD of three independent experiments. $* p<0.05$, ** $p<0.01$, *** $p<0.001 v s$. finasteride; ${ }^{\#} p<0.05,{ }^{\# \#} p<0.01,{ }^{\# \#} p<0.001$ vs. control.

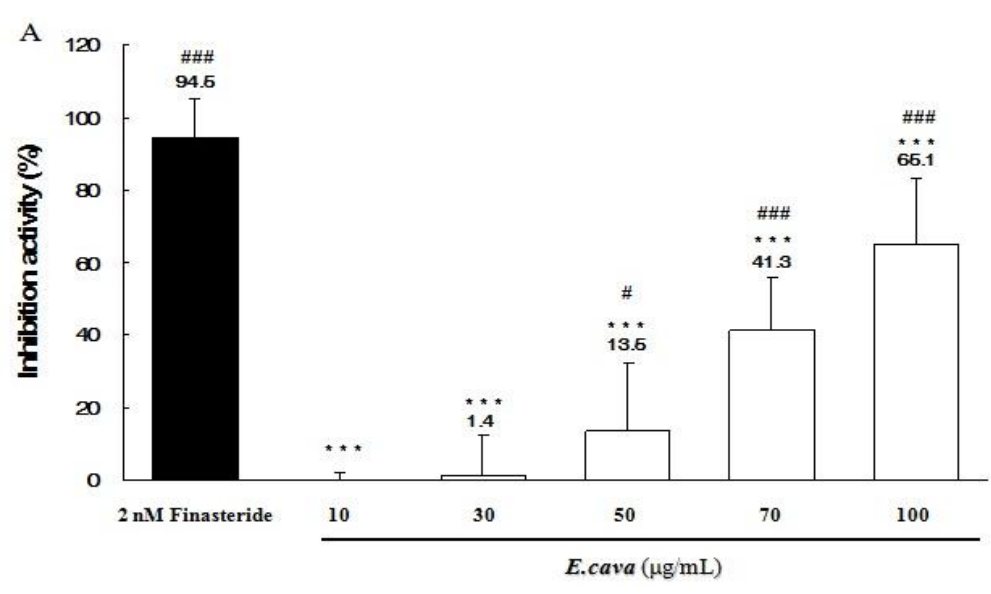


Figure 5. Cont.


$5 \alpha$-reductase activity is known to be important for preventing hair loss. We investigated the effects of E. cava enzymatic extract, eckol, dieckol, phloroglucinol and triphlorethol-A on the $5 \alpha$-reductase activity using rat prostatic enzyme. As shown in Figure 5, the E. cava enzymatic extract, eckol and dieckol significantly inhibited $5 \alpha$-reductase activities in a dose-dependent manner (Figure 5A-C). Especially, when the reaction mixture was incubated with $100 \mu \mathrm{g} / \mathrm{mL}$ of dieckol, its inhibition activity was similar to that of the finateride treated group, a positive control group (Figure 5C). However, phloroglucinol did not affect $5 \alpha$-reductase activities (Figure 5D). 5 $\alpha$-Reductase activities in the triphlorethol-A treated group showed a slight inhibition (Figure 5E).

\section{Discussion}

In this study, the hair growth promoting effect of $E$. cava enzymatic extract, which contains more than $35 \%$ of dieckol, was investigated in vitro and in vivo. To the best of our knowledge, this study is the first to demonstrate that $E$. cava enzymatic extract and dieckol, a component of $E$. cava, have the potential to promote hair growth via the proliferation of dermal papilla cells and/or the inhibition of $5 \alpha$-reductase activity.

The hair growth cycles, in hair follicle organ cultures of the rat vibrissa follicles, have been reported to be synchronized according to their age [28] and the isolated rat vibrissa follicles could be maintained in vitro up to 23 days [29]. Use of the organ culture methods to evaluate hair follicle growth is thought to be correlated with in vivo systems because the extent of hair growth can be observed as the sum of the function of each cell [30]. We found that the E. cava enzymatic extract increased the hair-fiber length of follicles by $12.4 \%$ at $1 \mu \mathrm{g} / \mathrm{mL}$, compared with the vehicle-treated control. To evaluate the in vivo effect of E. cava enzymatic extract on the induction of the anagen phase, the hair growth promoting effect on C57BL/6 mouse was examined. The hair growth stimulating in vitro effect of $E$. cava enzymatic extract was also observed in vivo using C57BL/6 mice. 
The hair follicle consists of several distinct epithelial cells and DPC [31,32]. Regulation of hair growth depends on the balance between proliferation and apoptosis in the DPC [10]. As shown in figure 3, E. cava enzymatic extract significantly increased the proliferation of DPC. We also examined whether the isolated compounds of E. cava extracts such as eckol, dieckol, phloroglucinol and triphlorethol-A, could increase the proliferation of DPC. We observed that eckol and dieckol increased the proliferation of DPC, whereas phloroglucinol and triphlorethol-A did not affect proliferation of DPC (Table 1).

$\mathrm{K}^{+}$channel opening is involved in not only mitogenesis [33], but also hair growth [34]. In previous studies, minoxidil was able to potentiate the mitogenic effects on NIH3T3 fibroblasts through the $\mathrm{K}_{\mathrm{ATP}}$ channel opening [35]. As shown in Figure 4, the E. cava enzymatic extract could promote the proliferation of NIH3T3 fibroblasts, which was inhibited by tobutamide, a non-selective blocker of $\mathrm{K}^{+}$ channels. The result indicates that the E. cava enzymatic extract can promote hair growth via the $\mathrm{K}_{\mathrm{ATP}}$ channel opening.

Inhibition of $5 \alpha$-reductase activity is important in preventing hair loss in AGA [36,37]. E. cava enzymatic extract significantly inhibited $5 \alpha$-reductase activity in a dose dependent manner. Among the isolated compounds from E. cava enzymatic extract-eckol, dieckol, phloroglucinol and triphlorethol-A — dieckol was the most active. The results suggest that E. cava enzymatic extract and dieckol could have the potential for the treatment of AGA via the inhibition of 5 $\alpha$-reductase activities. Previous studies propose that AGA may be caused by DHT in different ways: The miniaturization of dermal papilla and hair follicles is induced by DHT, which leads to transition from anagen to catagen [38]. DHT increases the levels of transforming growth factor- $\beta 1$ (TGF- $\beta 1$ ) and TGF- $\beta 2$ in dermal papilla cells, which leads to decreased proliferation of epithelial cells $[39,40]$. Up-regulation of dickkopf related protein-1 (DKK-1) by DHT can cause repression of the growth of epithelial cells in hair follicles [41]. In further studies, we need to examine whether that E. cava enzymatic extract and dieckol can regulate the levels of TGF- $\beta 1 / \beta 2$ and DKK-1 in dermal papilla cells. The androgen action and gene expressions in dermal papilla cells (DPCs) from the human beard are known to be different from those in DPCs of the human scalp. In the future, therefore, although the structure of hair follicle in the human scalp is very similar to that of hair follicle in rat vibrissa, we need to examine whether E. cava extract and dieckol can promote hair growth of the human scalp.

\section{Experimental Section}

\subsection{Alga Material}

The brown alga, E. cava, was collected along the coasts of Jeju Island in Korea, between February and May 2010 and taxonomically identified by Professor Ki Wan Lee. The samples were washed three times in tap water to remove any attached salt, epiphytes, and sand. Then, they were rinsed carefully with fresh distilled water, and maintained in a medical refrigerator at $-20{ }^{\circ} \mathrm{C}$. The frozen samples were then lyophilized and homogenized using a grinder prior to extraction. 


\subsection{Preparation of E. cava Enzymatic Extract}

We followed the methods reported in previous studies for the preparation of $E$. cava enzymatic extract [42]. To briefly state the preparation procedure, fifty grams of E. cava were homogenized with water $(2 \mathrm{~L}$ ), and mixed with $500 \mu \mathrm{L}$ of carbohydrate enzyme (celluclast 1.5L FG, Novozyme Nordisk, Bagsvaerd, Denmark). E. cava enzymatic extract was adjusted to be within the optimum $\mathrm{pH}$ and temperature range of the carbohydrate enzyme and enzymatic reactions were performed for $24 \mathrm{~h}$. Following extraction, the extract was boiled for $10 \mathrm{~min}$ at $100{ }^{\circ} \mathrm{C}$ to inactivate the enzymes. Then, E. cava enzymatic extract was clarified by centrifugation ( $3000 \mathrm{rpm}$, for $20 \mathrm{~min}$ at $4{ }^{\circ} \mathrm{C}$ ) to remove the residue. E. cava enzymatic extract was adjusted to $\mathrm{pH}$ 7.0.

\subsection{Extraction and Isolation of Phlorotannins from Ecklonia cava}

Eckol, dieckol, phloroglucinol and triphlorethol-A were isolated from E. cava as previously described [43]. In short, the dried E. cava was extracted three times with $80 \%$ aqueous EtOH, and was evaporated in a vacuum. The EtOH extract was then partitioned with EtOAc. The EtOAc fraction was subjected to silica and LH-20 column chromatography. The active compounds were finally purified by reversed-phase HPLC (ThermoFisher Scientific, San Jose, CA, USA), and the purified compounds were then confirmed by comparing their LC/MS, ${ }^{1} \mathrm{H}$ NMR data to those in the existing literature [43].

Eckol: LC/MS data $\left(\mathrm{M}^{+}, \mathrm{m} / z: 372.0\right.$ calcd for $\left.\mathrm{C}_{18} \mathrm{H}_{12} \mathrm{O}_{9}\right) .{ }^{1} \mathrm{H}$ NMR (400 MHz, DMSO-d6) $\delta 9.54$ (1H, s, OH-9), 9.45 (1H, s, OH-4), 9.21 (2H, s, OH-2,7) 9.16 (2H, s, OH-3',5'), 6.14 (1H, s, H-3), 5.96 $(1 \mathrm{H}, \mathrm{d}, \mathrm{J}=2.8 \mathrm{~Hz}, \mathrm{H}-8), 5.80\left(1 \mathrm{H}, \mathrm{d}, \mathrm{J}=1.7 \mathrm{~Hz}, \mathrm{H}-4^{\prime}\right), 5.78(1 \mathrm{H}, \mathrm{d}, \mathrm{J}=2.8 \mathrm{~Hz}, \mathrm{H}-6), 5.72(2 \mathrm{H}$, $\left.\mathrm{J}=1.7 \mathrm{~Hz}, \mathrm{H}-2^{\prime}, 6^{\prime}\right)$.

Dieckol: LC/MS data $\left(\mathrm{M}^{+}, m / z: 742.0\right.$ calcd for $\left.\mathrm{C}_{36} \mathrm{H}_{22} \mathrm{O}_{18}\right) .{ }^{1} \mathrm{H}$ NMR (400 MHz, DMSO-d6) $\delta$ 9.71(1H, s, OH-9), $9.61\left(1 \mathrm{H}, \mathrm{s}, \mathrm{OH}^{-9}{ }^{\prime \prime}\right), 9.51\left(1 \mathrm{H}, \mathrm{s}, \mathrm{OH}-4^{\prime \prime}\right), 9.46(1 \mathrm{H}, \mathrm{s}, \mathrm{OH}-4), 9.36(2 \mathrm{H}, \mathrm{s}$, OH-3",5"), 9.28 (1H, s, OH-2"), 9.23 (1H, s, OH-2), 9.22 (1H, s, OH-7"), 9.15 (2H, s, OH-3',5') 6.17 $\left(1 \mathrm{H}, \mathrm{s}, \mathrm{H}-3^{\prime \prime}\right), 6.14(1 \mathrm{H}, \mathrm{s}, \mathrm{H}-3), 6.02(1 \mathrm{H}, \mathrm{d}, \mathrm{J}=2.7 \mathrm{~Hz}, \mathrm{H}-8), 5.98\left(1 \mathrm{H}, \mathrm{d}, \mathrm{J}=2.7 \mathrm{~Hz}, \mathrm{H}-8^{\prime \prime}\right), 5.95(1 \mathrm{H}$, s, H-2', 6"'), $5.82(1 \mathrm{H}, \mathrm{d}, \mathrm{J}=2.7 \mathrm{~Hz}, \mathrm{H}-6), 5.81(1 \mathrm{H}, \mathrm{d}, \mathrm{J}=2.7 \mathrm{~Hz}, \mathrm{H}-6 "), 5.80(1 \mathrm{H}, \mathrm{t}$, $\left.\mathrm{J}=2.0 \mathrm{~Hz}, \mathrm{H}-4^{\prime}\right), 5.78\left(2 \mathrm{H}, \mathrm{d}, \mathrm{J}=2.0 \mathrm{~Hz}, \mathrm{H}-2^{\prime}, 6^{\prime}\right)$.

Phloroglucinol: LC/MS data $\left(\mathrm{M}^{+}, \mathrm{m} / z: 126\right.$ calcd for $\left.\mathrm{C}_{6} \mathrm{H}_{6} \mathrm{O}_{3}\right) .{ }^{1} \mathrm{H}$ NMR (400 MHz, DMSO-d6) $\delta$ 8.97 (3H, s, OH-1,3,5), 5.66 (3H, s, H-2,4,5).

Triphlorethol-A: LC/MS data $\left(\mathrm{M}^{+}, \mathrm{m} / z: 374.0\right.$ calcd for $\left.\mathrm{C}_{18} \mathrm{H}_{14} \mathrm{O}_{9}\right) .{ }^{1} \mathrm{H}$ NMR (400 $\mathrm{MHz}$, DMSO-d6) $\delta 5.7(1 \mathrm{H}, \mathrm{d}, J=2.7, \mathrm{H}-3), 6.0(1 \mathrm{H}, \mathrm{d}, J=2.9, \mathrm{H}-5), 5.8\left(1 \mathrm{H}, \mathrm{S}, \mathrm{H}-3^{\prime}\right), 5.8\left(1 \mathrm{H}, \mathrm{S}, \mathrm{H}-5^{\prime}\right)$, $6.0\left(1 \mathrm{H}, \mathrm{d}, J=2.2, \mathrm{H}-2^{\prime \prime}\right), 5.9\left(\mathrm{t}, J=2.2, \mathrm{H}-4^{\prime \prime}\right), 6.0\left(1 \mathrm{H}, \mathrm{d}, J=2.2, \mathrm{H}-6^{\prime \prime}\right)$.

The purity of eckol, dieckol, phloroglucinol and triphlorethol-A was $>95 \%$, according to the peak area of all components absorbed at each specific wavelength in HPLC analysis. Their chemical structures are shown in Figure 6, and were freshly dissolved in dimethyl sulfoxide (DMSO) (Sigma, St. Louis, MO, USA) for subsequent treatment. Further, minoxidil sulfate and minoxidil were also dissolved in DMSO for subsequent treatment. The final concentration of DMSO was adjusted to $0.2 \%$ $(\mathrm{v} / \mathrm{v})$ in the following experiment. Tolbutamide was made up as a $410 \mathrm{mM}$ stock solution in ethanol and added to the culture media in a final concentration of $0.25 \%$ ethanol. 
Figure 6. Structures of eckol, dieckol, phloroglucinol and triphlorethol-A.

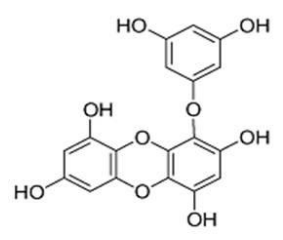

Eckol

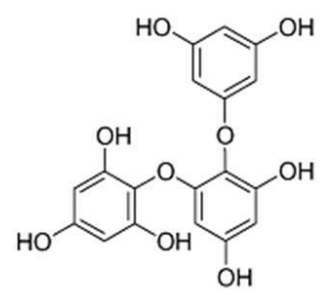

Triphlorethol-A

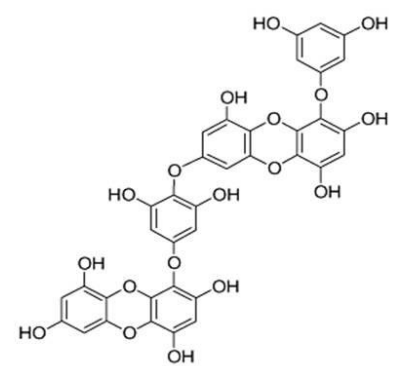

Dieckol

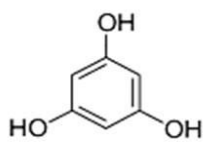

Phloroglucinol

\subsection{Animals}

Male Wistar rats (3 weeks of age) were supplied from Orient Bio (Seongnam, Gyeonggi, Korea). Six-week-old female C57BL/6 mice and 8-week-old male spargue-Dawley (SD) rats were purchased from Dae-Han Biolink (Eumsung, Chungbuk, Korea) and were provided with a standard laboratory diet and water ad libitum. All animals were cared for by using protocols (20100031) approved by the Institutional Animal Care and Use Committee (IACUC) of the Jeju National University.

\subsection{Isolation and Culture of Rat Vibrissa Follicles}

Isolation of rat vibrissa follicles was performed as described previously [29]. Briefly, rat vibrissa follicles were harvested from male Wistar rats that were 23 days old. To accomplish this, the rats were sacrificed under carbon dioxide $\left(\mathrm{CO}_{2}\right)$. Next, both the left and right mystacial pads were removed from the rats and placed in a 1:1 (v/v) solution between Earle's balanced salts solution (EBSS, Sigma, St. Louis, MO, USA) and PBS that contained $100 \mathrm{unit} / \mathrm{mL}$ of penicillin and $100 \mu \mathrm{g} / \mathrm{mL}$ of streptomycin. Anagen vibrissa follicles were then carefully dissected under a stereomicroscope (Olympus, Tokyo, Japan) from posterior parts of the mystacial pads, with considerable caution to remove the surrounding connective tissue without damaging the vibrissa follicle. Using this method, we were able to routinely isolate more than 40 follicles from each animal. The isolated follicles were then placed in separate wells in 24-well plates that contained $500 \mu \mathrm{L}$ of Williams medium $\mathrm{E}$ (GIBCO Inc, Grand Island, NY, USA) supplemented with $2 \mathrm{mM}$ L-glutamine (Gibco Inc, Grand Island, NY, USA), $10 \mu \mathrm{g} / \mathrm{mL}$ insulin (Sigma, St. Louis, MO, USA), $50 \mathrm{nM}$ hydrocortisone (Sigma, St. Louis, MO, USA), 100 unit/mL penicillin and $100 \mu \mathrm{g} / \mathrm{mL}$ streptomycin at $37{ }^{\circ} \mathrm{C}$. They were cultivated in an atmosphere comprised of $5 \% \mathrm{CO}_{2}$ and $95 \%$ air. The isolated follicles were then treated with vehicle (DMSO diluted 1:1000 in Williams medium E) as a control and E. cava enzymatic extract $(0.01,0.1,1$ and $10 \mu \mathrm{g} / \mathrm{mL}$ ). Minoxidil sulfate (Sigma, St. Louis, MO, USA) was used as a positive control in the 
culture systems (Buhl et al., 1990). The culture medium was changed every 3 days and photographs of the cultured vibrissa follicles were taken using a stereomicroscope, for 3 weeks. The length of the hair follicles was measured using a DP controller (Olympus, Tokyo, Japan).

\subsection{Hair Growth Activity in Vivo}

Anagen was induced on the back skin of C57BL/6 mice that were in the telogen phase of the cycle by depilation, as described previously [27]. Briefly, 6-week-old female C57BL/6 mice were allowed to adapt to their new environment for one week. The anagen was then induced in the back skin of the 7-week-old female C57BL/6 mice by shaving, which led to synchronized development of anagen hair follicles. From the following day (day 1), $0.2 \mathrm{~mL}$ of $0.5 \%$ E. cava enzymatic extract in $50 \%$ ethanol was topically applied every day for 33 days. 5\% Minoxidil (MINOXYL ${ }^{\mathrm{TM}}$; Hyundai Pharm. Co. Ltd., Cheonan, Chungnam, Korea) was used as a positive control. The back skin of the mice was then observed and photographed at 1, 7, 13, 20, 26 and 33 days after shaving. For the quantitative assessment, dotmatrix planimetry was performed [44].

\subsection{Culture and Proliferation Assay of Dermal Papilla Cells}

Rat vibrissa immortalized dermal papilla cell line [45] was donated by the Skin Research Institute, Amore Pacific Corporation R \& D Center, South Korea. The DPC were cultured in DMEM (Hyclone Inc., Logan, UT, USA), supplemented with 10\% fetal bovine serum (Gibco BRL, Grand Island, NY, USA) and penicillin/streptomycin (100 unit/mL and $100 \mu \mathrm{g} / \mathrm{mL}$, respectively), at $37{ }^{\circ} \mathrm{C}$ in a humidified atmosphere under $5 \% \mathrm{CO}_{2}$.

The proliferation of DPC was evaluated by measuring the metabolic activity using a 3-[4,5-dimethylthiazol-2-yl]-2,5-diphenyltetrazolium bromide (MTT) [46]. Briefly, DPC at $1.0 \times 10^{4}$ cells $/ \mathrm{mL}$ were seeded into $96-$ well plate, then cultured for $24 \mathrm{~h}$ in a serum-free DMEM, and then treated with vehicle (DMSO diluted 1:1000 in serum-free DMEM) as a control, E. cava extract $(0.001 \sim 100 \mu \mathrm{g} / \mathrm{mL})$, eckol $(0.005 \sim 10 \mu \mathrm{g} / \mathrm{mL})$, dieckol $(0.005 \sim 10 \mu \mathrm{g} / \mathrm{mL})$, phloroglucinol $(0.005 \sim 10 \mu \mathrm{g} / \mathrm{mL})$, triphlorethol-A $(0.005 \sim 10 \mu \mathrm{g} / \mathrm{mL})$ and minoxidil sulfate $(1 \mu \mathrm{M})$, for 4 days. After incubation, $0.1 \mathrm{mg}(50 \mu \mathrm{L}$ of a $2 \mathrm{mg} / \mathrm{mL}$ solution) of MTT (Sigma, St. Louis, MO, USA) was added to each well, and the cells were then incubated at $37^{\circ} \mathrm{C}$ for $4 \mathrm{~h}$. Next, the plates were centrifuged at $1000 \mathrm{rpm}$ for $5 \mathrm{~min}$ at room temperature and the media was then carefully aspirated. $200 \mu \mathrm{L}$ of DMSO was then added to each well to dissolve the formazan crystals and the absorbance of the plates, at $540 \mathrm{~nm}$, was then read immediately on a microplate reader (BioTek Instrument, Inc., Winooski, VT, USA). All experiments were performed three times and the mean absorbance values were calculated. The results are expressed as a percentage of absorbance caused by treatment with the extract or the active component compared to those of the vehicle treated controls.

\subsection{Culture and Proliferation Assay of NIH3T3 Fibroblasts}

The mouse embryonic NIH3T3 fibroblasts were purchased from ATCC (Rockville, MD, USA) and cultured in ATCC-formulated Dulbecco's Modified Eagle's Medium (DMEM), supplemented with 10\% 
(v/v) heat-activated bovine calf serum (BCS), $100 \mathrm{unit} / \mathrm{mL}$ penicillin and $100 \mu \mathrm{g} / \mathrm{mL}$ streptomycin at $37{ }^{\circ} \mathrm{C}$ atmosphere and $5 \% \mathrm{CO}_{2}$.

The proliferation of NIH3T3 fibroblasts was also evaluated by measuring the metabolic activity using MTT assay [46]. NIH3T3 fibroblasts, at $1.0 \times 10^{4}$ cells $/ \mathrm{mL}$, were seeded into a 96-well plate. Cells were incubated for $24 \mathrm{~h}$ with DMEM supplemented with $10 \% \mathrm{BCS}$, then washed with phosphate buffered saline (PBS, Sigma, St. Louis, MO, USA). The cells were maintained with DMEM supplemented with $10 \%$ BCS or $1.5 \%$ BCS and treated with vehicle (DMSO) as a control, E. cava extract $(0.05 \sim 10 \mu \mathrm{g} / \mathrm{mL})$, eckol $(0.05 \sim 10 \mu \mathrm{g} / \mathrm{mL})$, dieckol $(0.05 \sim 10 \mu \mathrm{g} / \mathrm{mL})$, phloroglucinol $(0.05 \sim 10 \mu \mathrm{g} / \mathrm{mL})$, triphlorethol-A $(0.05 \sim 10 \mu \mathrm{g} / \mathrm{mL})$ and minoxidil $(75 \mu \mathrm{M})$, for 4 days. To clarify whether proliferation of NIH3T3 fibroblasts is regulated by $\mathrm{K}_{\mathrm{ATP}}$ channel opening, NIH3T3 fibroblasts were pretreated with tolbutamide $(2 \mathrm{mM})$, a non-selective blocker of $\mathrm{K}^{+}$channel, for 30 min prior to incubation with E. cava enzymatic extract for 4 days. All experiments were performed three times and the mean absorbance values were calculated. The results are expressed as the percentage in the absorbance caused by treatment with the extract or the active component compared to those of the vehicle untreated controls.

\subsection{Assay of Rat Prostatic 5 $\alpha$-Reductase}

Male SD rats (8 weeks) were sacrificed with carbon dioxide $\left(\mathrm{CO}_{2}\right)$. The prostates of rats were dissected, freed of their capsules, then washed with saline, and stored at $-80{ }^{\circ} \mathrm{C}$. Frozen tissues were thawed on ice and procedures were carried out at $4{ }^{\circ} \mathrm{C}$. The tissues were homogenized with Polytron homogenizer (Brinkman Instruments, Wesrbury, NY, USA) in 5-6 tissue volumes of medium A (0.32 M sucrose, $1 \mathrm{mM}$ dithiothreitol (DTT), $0.2 \mathrm{mM}$ phenylmethylsulfonylfluoride (PMSF), and $20 \mathrm{mM}$ potassium phosphate buffer $\mathrm{pH}$ 6.6). The homogenates were centrifuged at 100,000 $\mathrm{g}$ for $60 \mathrm{~min}$. The pellets were recovered, washed with three tissue volumes of medium A and centrifuged two additional times at $400 \mathrm{~g}$ at $0{ }^{\circ} \mathrm{C}$ for $10 \mathrm{~min}$. The washed pellets were suspended in medium $\mathrm{A}$ and stored at $-80{ }^{\circ} \mathrm{C}$ until use. The suspension $(2.5 \mathrm{mg}$ protein/mL for Rat prostates, determined by the Bradford method) was used as source of $5 \alpha$-reductase.

$5 \alpha$-reductase activities were assayed as previously described [47]. The reaction mixture contained a final volume of $500 \mu \mathrm{L}$ : one millimole DTT, $40 \mathrm{mM}$ potassium phosphate buffers, $2 \mathrm{mM} \mathrm{NADPH}$, Testosterone including $120 \mathrm{n} \mathrm{Ci}\left[1,2,6,7-{ }^{3} \mathrm{H}\right]$. The reaction in triplicate was started when it was added to the rat prostatic enzyme fraction $(250 \mu \mathrm{g}$ protein), $0.2 \% \mathrm{DMSO}$ as a control, E. cava extract (10, 30, 50, 70 and $100 \mu \mathrm{g} / \mathrm{mL}$ ), eckol (10, 70 and $100 \mu \mathrm{g} / \mathrm{mL})$, dieckol (10, 70 and $100 \mu \mathrm{g} / \mathrm{mL}$ ), phloroglucinol $(10,70$ and $100 \mu \mathrm{g} / \mathrm{mL})$ and triphlorethol-A $(10,70$ and $100 \mu \mathrm{g} / \mathrm{mL})$. Finasteride $2 \mathrm{nM}$ (MERCK SHARP \& DOHME, South Granville, Australia) was used as a positive control. The mixture was incubated at $37{ }^{\circ} \mathrm{C}$ for $60 \mathrm{~min}$, and then stopped by adding $1 \mathrm{~mL}$ of ethyl acetate and mixing for $1 \mathrm{~min}$. After centrifugation at $1000 \mathrm{~g}$ for $5 \mathrm{~min}$, the organic phase was removed which then was dried under a heating plate, dissolved in $50 \mu \mathrm{L}$ of ethyl acetate containing $500 \mu \mathrm{g} / \mathrm{mL}$ testosterone and $500 \mu \mathrm{g} / \mathrm{mL}$ dihydrotestosterone (DHT) and applied to a silica gel 60 F254 TLC plate (Merck, Darmstadt, Germany). The plate was developed in a solvent system consisting of an ethyl acetate:cyclohexane $(1: 1)$ solution, the plate then was air dried. Testosterone was visibly seen under the UV light $(254 \mathrm{~nm})$ and DHT was detected using $10 \% \mathrm{H}_{2} \mathrm{SO}_{4}$ solution via posteriorly heating the 
plate. Under these conditions, DHT will be shown as a dark yellow color. Areas containing androgen were removed and the strips were soaked in the $5 \mathrm{~mL}$ of ULTIMA GOLD ${ }^{\mathrm{TM}}$ Cocktails (PerkinElmer, Inc., Waltham, MA, USA) and the radioactivity level was then measured via a liquid scintillation counter (Packard Bioscience, Meriden, CT, USA). The activity of $5 \alpha$-reductase was expressed as the ratio $[\mathrm{DHT} /(\mathrm{T}+\mathrm{DHT})] \times 100$.

\subsection{Statistical Analyses}

Each experiment was performed at least in triplicate. Results are expressed as mean \pm SD or mean \pm SE from three separate experiments. The Student's $t$ test and one-way ANOVA test were used to determine the statistical significance.

\section{Conclusions}

In conclusion, this study demonstrated that dieckol, a principal component of E. cava, could stimulate hair growth through the proliferation of dermal papilla cells and the inhibition of $5 \alpha$-reductase activity. These finding indicate that dieckol from E. cava enzymatic extract is a possible therapeutic compound for treatment of hair loss.

\section{Acknowledgments}

This research was a part of the project titled "Development of product and material promoting hair-growth from Jeju marine algae" funded by the Ministry of Land, Transport and Maritime Affairs, Korea.

\section{References}

1. Cotsarelis, G.; Millar, S.E. Towards a molecular understanding of hair loss and its treatment. Trends Mol. Med. 2001, 7, 293-301.

2. Price, V.H. Treatment of hair loss. N. Engl. J. Med. 1999, 341, 964-973.

3. Kaufman, K.D.; Olsen, E.A.; Whiting, D.; Savin, R.; DeVillez, R.; Bergfeld, W.; Price, V.H.; van Neste, D.; Roberts, J.L.; Hordinsky, M.; et al. Finasteride in the treatment of men with androgenetic alopecia. Finasteride Male Pattern Hair Loss Study Group. J. Am. Acad. Dermatol. 1998, 39, 578-589.

4. Burton, J.L.; Marshall, A. Hypertrichosis due to minoxidil. Br. J. Dermatol. 1979, 101, 593-595.

5. Gromley, G.J. Finasteride: A clinical review. Biomed. Pharmacother. 1995, 49, 319-324.

6. McClellan, K.J.; Markham, A. Finasteride: A review of its use male pattern hair loss. Drugs 1999, 57, 111-126.

7. Mehta, P.K.; Mamdani, B.; Shansky, R.M.; Mahurkar, S.D.; Dunea, G. Severe hypertension. Treatment with minoxidil. J. Am. Med. Assoc. 1975, 233, 249-252.

8. Tanigaki-Obana, N.; Ito, M. Effects of cepharanthine and minoxodil on proliferation, differentiation and keratinozation of cultured cells from the murine hair apparatus. Arch. Dermatol. Res. 1992, 284, 290-296. 
9. Uno, H.; Cappas, A.; Schlagel, C. Cyclic dynamics of hair follicles and the effect of minoxidil on the bald scalps of stumptailed macaques. Am. J. Dermatopathol. 1985, 7, 283-297.

10. Han, J.H.; Kwon, O.S.; Chung, J.H.; Cho, K.H.; Eun, H.C.; Kim, K.H. Effect of minoxodil on proliferation and apoptosis in dermal papilla cells of human hair follicle. J. Dermatol. Sci. 2004, 34, 91-98.

11. Hamaoka, H.; Minakuchi, K.; Miyoshi, H.; Arase, S.; Chen, C.H.; Nakaya, Y. Effect of $\mathrm{K}^{+}$ channel openers on $\mathrm{K}^{+}$channel in cultured human dermal papilla cells. J. Med. Invest. 1997, 44, 73-77.

12. Shorter, K.; Farjo, N.P.; Picksley, S.M.; Randall, V.A. Human hair follicles contain two forms of ATP-sensitive potassium channels, only one of which is sensitive to minoxidil. FASEB J. 2008, 22, 1725-1736.

13. Lachgar, S.; Moukadiri, H.; Jonca, F.; Charveron, M.; Bouhaddioui, N.; Gall, Y.; Bonafe, J.L.; Plouet, J. Vascular endothelial growth factor is an autocrine growth factor for hair dermal papilla cells. J. Invest. Dermatol. 1996, 106, 17-23.

14. Kwack, M.H.; Kang, B.M.; Kim, M.K.; Kim, J.C.; Sung, Y.K. Minoxidil activates beta-catenin pathway in human dermal papilla cells: A possible explanation for its anagen prolongation effect. J. Dermatol. Sci. 2011, 62, 154-159.

15. Itami, S.; Kurata, S.; Takayasu, S. Androgen induction of follicular epithelial cell growth is mediated via insulin-like growth factor-I from dermal papilla cells. Biochem. Biophys. Res. Commun. 1995, 212, 988-994.

16. Shimaoka, S.; Imai, R.; Ogawa, H. Dermal papilla cells express hepatocyte growth factor. J. Dermatol. Sci. 1994, 7, S79-S83.

17. Soma, T.; Dohrmann, C.E.; Hibino, T.; Raftery, L.A. Profile of transforming growth factor-beta responses during the murine hair cycle. J. Invest. Dermatol. 2003, 121, 65-68.

18. Soma, T.; Tsuji, Y.; Hibino, T. Involvement of transforming growth factor-beta2 in catagen induction during the human hair cycle. J. Invest. Dermatol. 2002, 118, 993-997.

19. Choi, J.G.; Kang, O.H.; Brice, O.O.; Lee, Y.S.; Chae, H.S.; Oh, Y.C.; Sohn, D.H.; Park, H.; Choi, H.G.; Kim, S.G.; et al. Antibacterial activity of Ecklonia cava against methicillin-resistant Staphylococcus aureus and Salmonella spp. Foodborne. Pathog. Dis. 2010, 7, 435-441.

20. Kim, T.H.; Bae, J.S. Ecklonia cava extracts inhibit lipopolysaccharide induced inflammatory responses in human endothelial cell. Food Chem. Toxicol. 2010, 48, 1682-1687.

21. Ahn, M.J.; Yoon, K.D.; Min, S.Y.; Lee, J.S.; Kim, J.H.; Kim, T.G.; Kim, S.H.; Kim, N.G.; Huh, H.; Kim, J. Inhibition of HIV-1 reverse transcriptase and protease by phlorotannins from the brown alga Ecklonia cava. Biol. Pharm. Bull. 2004, 27, 544-547.

22. Kang, K.A.; Lee, K.H.; Chae, S.; Koh, Y.S.; Yoo, B.S.; Kim, J.H.; Ham, Y.M.; Baik, J.S.; Lee, N.H.; Hyun, J.W. Triphlorethol-A from Ecklonia cava protects V79-4 lung fibroblast against hydrogen peroxide induced cell damage. Free Radic. Res. 2005, 39, 883-892.

23. Kang, K.A.; Lee, K.H.; Park, J.W.; Lee, N.H.; Na, H.K.; Surh, Y.J.; You, H.J.; Chung, M.H.; Hyun, J.W. Triphlorethol-A induces heme oxygenase-1 via activation of ERK and NF-E2 related factor 2 transcription factor. FEBS Lett. 2007, 581, 2000-2008. 
24. Kong, C.S.; Kim, J.A.; Yoon, N.Y.; Kim, S.K. Induction of apoptosis by phloroglucinol derivative from Ecklonia cava in MCF-7 human breast cancer cells. Food Chem. Toxicol. 2009, 47, 1653-1658.

25. Park, E.; Ahn, G.N.; Lee, N.H.; Kim, J.M.; Yun, J.S.; Hyun, J.W.; Jeon, Y.J.; Wie, M.B.; Lee, Y.J.; Park, J.W.; Jee, Y. Radioprotective properties of eckol against ionizing radiation in mice. FEBS Lett. 2008, 582, 925-930.

26. Jung, W.K.; Heo, S.J.; Jeon, Y.J.; Lee, C.M.; Park, Y.M.; Byun, H.G.; Choi, Y.H.; Park, S.G.; Choi, I.W. Inhibitory effects and molecular mechanism of dieckol isolated from marine brown alga on COX-2 and iNOS in microglial cells. Agric. Food Chem. 2009, 57, 4439-4446.

27. Müller-Röver, S.; Handjiski, B.; van der Veen, C.; Maurer, M.; Eichmüller, S.; Ling, G.; Hofmann, U.; Foitzik, K.; Mecklenburg, L.; Handjiski, B. A comprehensive guide for the accurate classification of murine hair follicles in distinct hair cycle stages. J. Invest. Dermatol. 2001, 117, 3-15.

28. Ibrahim, L.; Wright, E.A. The growth of rats and mice vibrissae under normal and some abnormal conditions. J. Embryol. Exp. Morphol. 1975, 33, 831-844.

29. Philpott, M.P.; Kealey, T. Cyclical changes in rat vibrissa follicles maintained in vitro. J. Invest. Dermatol. 2000, 115, 1152-1155.

30. Philpott, M.P.; Green, M.R.; Kealey, T. Human hair growth in vitro. J. Cell Sci. 1990, 97, 463-471.

31. Botchkarev, V.A.; Kishimoto, J. Molecular control of epithelial-mesenchymal interactions during hair follicle cycling. J. Investig. Dermatol. Symp. Proc. 2003, 8, 46-55.

32. Paus, R.; Cotsarelis, G. The biology of hair follicles. N. Engl. J. Med. 1999, 341, 491-497.

33. Dubois, J.M.; Rouzaire-Dubois, B. Role of potassium channels in mitogenesis. Prog. Biophys. Mol. Biol. 1993, 59, 1-21.

34. Harmon, C.S.; Lutz, D.; Ducote, J. Potassium channel openers stimulate DNA synthesis in mouse epidermal keratinocyte and whole hair follicle cultures. Skin Pharmacol. 1993, 6, 170-178.

35. Sanders, D.A.; Fiddes, I.; Thompson, D.M.; Philpott, M.P.; Westgate, G.E.; Kealey, T. In the absence of streptomycin, minoxidil potentiates the mitogenic effects of fetal calf serum, insulin-like growth factor 1 , and platelet-derived growth factor on NIH 3 T3 fibroblasts in a $\mathrm{K}^{+}$ channel-dependent fashion. J. Invest. Dermatol. 1996, 107, 229-234.

36. Whiting, D.A. Male pattern hair loss: Current understanding. Int. J. Dermatol. 1998, 37, 561-566.

37. Trüeb, R.M. Molecular mechanisms of androgenetic alopecia. Exp. Gerontol. 2002, 37, 981-990.

38. Sinclair, R. Male pattern androgenetic alopecia. BMJ 1998, 317, 865-869.

39. Hibino, T.; Nishiyama, T. Role of TGF-beta2 in the human hair cycle. J. Dermatol. Sci. 2004, 35, 9-18.

40. Inui, S.; Fukuzato, Y.; Nakajima, T.; Yoshikawa, K.; Itami, S. Androgen-inducible TGF-beta1 from balding dermal papilla cells inhibits epithelial cell growth: A clue to understand paradoxical effects of androgen on human hair growth. FASEB J. 2002, 16, 1967-1969.

41. Kwack, M.H.; Sung, Y.K.; Chung, E.J.; Im, S.U.; Ahn, J.S.; Kim, M.K.; Kim, J.C. Dihydrotestosterone-inducible dickkopf 1 from balding dermal papilla cells causes apoptosis in follicular keratinocytes. J. Invest. Dermatol. 2008, 128, 262-269.

42. Heo, S.J.; Jeon, Y.J.; Lee, J.; Kim, H.T.; Lee, K.W. Antioxidant effect of enzymatic hydrolyzates from a Kelp, Ecklonia cava. Algae 2003, 18, 341-347. 
43. Li, Y.; Qian, Z.J.; Ryu, B.M.; Lee, S.H.; Kim, M.N.; Kim, S.K. Chemical components and its antioxidant properties in vitro: An edible marine brown alga, Ecklonia cava. Bioorg. Med. Chem. 2009, 17, 1963-1973.

44. Ohnemus, U.; Uenalan, M.; Conrad, F.; Handjiski, B.; Mecklenburg, L.; Nakamura, M.; Inzunza, J.; Gustafsson, J.A.; Paus, R. Hair cycle control by estrogens: Catagen induction via estrogen receptor (ER)-alpha is checked by ER beta signaling. Endocrinology 2005, 146, 1214-1225.

45. Filsell, W.; Little, J.C.; Stones, A.J.; Granger, S.P.; Bayley, S.A. Transfection of rat dermal papilla cells with a gene encoding a temperature-sensitive polyomavirus large $\mathrm{T}$ antigen generates cell lines a differentiated phenotype. J. Cell Sci. 1994, 107, 1761-1772.

46. Carmichael, J.; DeGraff, W.G.; Gazdar, A.F.; Minna, J.D.; Mitchell, J.B. Evaluation of a tetrazolium-based semiautomated colorimetric assay: Assessment of chemosensitivity testing. Cancer Res. 1987, 47, 936-942.

47. Hirosumi, J.; Nakayama, O.; Fagan, T.; Sawada, K.; Chida, N.; Inami, M.; Takahashi, S.; Notsu, Y.; Okuhara, M.J. FK143, a novel nonsteroidal inhibitor of steroid 5-reductase: (1) In vitro effects on human and animal prostatic enzymes. Steroid. Biochem. Mol. Biol. 1995, 52, 357-363.

(C) 2012 by the authors; licensee MDPI, Basel, Switzerland. This article is an open access article distributed under the terms and conditions of the Creative Commons Attribution license (http://creativecommons.org/licenses/by/3.0/). 